\title{
Refugee Related Organisations in Greece and their Cooperation Networks in the Context of the European Asylum Regime
}

\author{
By Anna Gansbergen* \\ Tobias Breuckmann
}

In the last ten years, Greece grew to a main country of destination for asylum seekers trying to make their way to Europe. The Greek politics of asylum were, with short interruptions, rather reactive than proactive and led to desolate situations for people seeking protection. Even now, when the left wing-party SYRIZA announced improvements in asylum politics and living conditions, it seems difficult to provide appropriate service for people in search for a safe life. Refugee related organisations try to fill this gap between talk and action in Greece. This paper concentrates on how these networks affect the work and formal structure of organisations. Therefore, expert interviews were conducted. As main results, NGOs were fighting with decreasing financial support and therefore tried to help each other through networks to share resources and experiences, so mainly they are influencing each other on multiple levels.

Keywords: Common European asylum system, Organisational networks, Refuge related organisations.

\section{Introduction}

The mismatch between aspirations and reality in European asylum policy could not be bigger during the last years: While the EU claims to be an area of freedom, security and justice, the actual situation of those seeking protection from persecution is reflected not only in thousands of deaths in the Mediterranean Sea, but in the rapidly increasing number of people trying to enter the EU irregularly: During 2015, more than one million people crossed the Mediterranean Sea (UNHCR 2015). People who reach Europe are facing very unequal living conditions varying from one member state to another. Obviously, there is a considerable gap between official declarations (talk) and the actual behavior (action) by the EU, member states governments as well as governmental and non-governmental organisations. Up till now, neither a rational-realist perspective nor a value-based approach could add satisfactory contributions to a scientific explanation of the paradox regarding the Common European Asylum System (CEAS) and its implementation in the member states (Gansbergen and Pries 2016).

\footnotetext{
${ }^{*}$ Research Associate, Ruhr-University Bochum, Germany.

* Student, Ruhr-University Bochum, Germany.
} 
The interdisciplinary research project "Mapping Refugees' Arrivals at the Mediterranean Borders (MAREM)" aims to fill this research gap, using a theoretical approach based on the theory of neo-institutionalism (Meyer and Rowan 1977, DiMaggio and Powell 1983, Oliver 1991). Since the CEAS is a supranational framework of unbalanced power relations, legitimation strategies of organisations towards their organisational field (talk) are decoupled from organisational behavior (action). However, it could be supposed that collective actors at multiple levels are increasingly intertwined, leading, in the long run, to an European public space of asylum issues where collective actors have to legitimise themselves (Gansbergen and Pries 2016, Pries and Gansbergen 2016).

In this paper, the organisational actors related to asylum issues in Greece will be analysed. The primary goal of our research is to shed light on the role of refugee and asylum related organisations (RAROs) and their cooperation networks which can play a role for the development of the national and the European asylum system.

Regarding to that focus on the networks of RAROs, following questions are raised:

1. In how far and how do refugee and asylum related organisations in Greece cooperate with each other?

2. Which functions do fulfill these organisations and their cooperation networks regarding to the work of these organisations?

3. In how far do the networks influence the work and the underlying paradigms of the refugee and asylum related organisations in Greece?

At the beginning of the 2010s, Italy and Spain stood in the spotlight of the media regarding European asylum politics. At the same time the public interest towards Greece grew constantly and Greece was defined as the European problem area once again, where migrants from the Middle East may invade into Europe uncontrolled and unlimited (Cabot 2014: 29).

At least since 2010, as the global financial crisis took place especially in Southern Europe, Greece is seen as the weakest link of European refugees management (Triandafyllidou 2014: 410). Especially reported human rights violations to refugees by Greek officials as well as by the European border control of Frontex in detention camps raised special attention in organisations work and reports as well as in European Courts (Kalpouzos and Mann 2015: 3).

In Greece, the change of governments in 2015 and the enormous rise of numbers of asylum seekers (UNHCR 2016b: 1) raise special questions, especially how the refugees situation is changing and how the work and the networks of refugee related NGOs develop. The research is mainly based on empirical fieldwork in Athens in 2014, 2015 and 2016 consisting of expert interviews with representatives of refugee related organisations and an analysis of secondary sources. 


\section{The Asylum Politics in Greece and the Situation for Asylum Seekers}

Due to its geopolitical position in Europe, Greece is seen as a country of indispensable strategical significance but is at the same time often perceived as an area of crises (Cabot 2014: 3; Kalpouzos and Mann 2015: 3). Since 2004, the country has one of the highest numbers of asylum seekers in Europe, but one of the lowest recognition rates (Cabot 2014: 4). The high amount of rejections is an issue, but an even more important issue is the high number of pending requests for asylum in Greece (Cabot 2014: 4). The overall crisis in Greece highly affects everyday practice regarding processes in asylum applications as well as the social integration of refugees (Cabot 2014: 10).

\section{The Recent State and Developments of Migration Politics in Greece}

Even if some migration laws were developed, no long term plan of dealing with migration has emerged in Greece until 2010, so that there was no political agenda other than being reactive to the constant and recently rising number of migrants (Triandafyllidou 2014: 411). Since 2010, a change in migration and citizenship policy by the socialist government (PASOK) took place (Triandafyllidou 2014: 411). Triandafyllidou (2014) specifies this change as follows:

"When the Socialist party came to power in October 2009, it quickly proceeded to change the citizenship law, in keeping with its electoral promises, to facilitate naturalization for non-Greek origin immigrants. In March 2010, the Greek Parliament adopted the law 3838/2010 on citizenship and naturalization. The new law lowered the requirement for naturalization from 10 to 7 years of legal residence in Greece" (Triandafyllidou 2014: 414).

This trend to liberalise the migration and citizenship law was fastly inverted resulting in the annulment of the 2010 Citizenship Law. In 2012, when the conservative party New Democracy was elected, they put back the citizenship law into the state of 2010 (Triandafyllidou 2014: 418). In 2010, also an asylum procedure was installed, which enhanced the transparency and efficiency of the process in the first instance and transported responsibilities into an independent council (Cabot 2014: 35, Triandafyllidou 2014: 419).

The change of migration law leading to citizenship of foreigners resulted from EU directives and can be seen as a consequence of Europeanisation. Triandafyllidou (2014) argues that this is a result of official and political Europeanisation, but the discourse of the political elite seems opposed to getting votes by citizens linked to the financial crisis especially in Greece, which can be seen as a decisive factor of the annulation of the migration policies (Triandafyllidou 2014: 412). This also shows a strong effect of multilevel factors on national politics and discourses, which are standing in stress ratio within different paradigms and requirements. These developments 
have a strong effect on the asylum seekers situation in Greece as well as the work and cooperation networks of RAROs.

\section{The Sociopolitical Situation for Asylum Seekers and Refugees in Greece}

In Greece, asylum seekers are facing many challenges such as difficulties in finding accomodation, social support and taking the high obstacles during the application process (Cabot 2014: 23). There is a combination of the lack of bureaucratic capacities, the effects of the global financial crisis and the position of Greece as a border state affecting the social and legal situation of asylum seekers. Also the overall difficult situation in Greece, leading to the marginalisation and poverty in parts of the population, affects the social and ethical dynamics regarding the coexistence with asylum seekers and refugees (Cabot 2014: 6). This led for example to the rise of extremist right wing opinions and political parties such as Golden Dawn, but also rising numbers of protest and attacks against migrants (Georgiadou and Rori 2013: 332).

Next to the rejection of asylum applications in Greece, the high number of pending applications remains a serious problem for people seeking protection. Because these processes can last up to a year or more, where people remain "illegal" and get less help from governmental institutions, many applicants continue their journey further to western Europe, remain in marginality in Greece or even try to get back to their home countries (Cabot 2014: 32). Especially the situation of asylum seekers in Greek detention centres seems disturbing, as Kalpouzos and Mann (2015) state in their paper on human rights violations during asylum procedure in Greece:

"The cumulative picture was alarming. Greek detention centres held migrants in extremely poor sanitary conditions, often in enormously overpopulated cells, with little or no access to medical services. The duration of incarceration in such conditions varied, but could be as short as a few hours and as long as over 18 months. [...] The cells have often been repurposed cement boxes designed originally for freight storage" (Kalpouzos and Mann 2015: 5 f.).

During the arrest in the detention centres, people get no legal status and some of them are in fear of being sent back if they demand their rights of applying for asylum in Greece. Also, the time of arrest can be extended to an unlimited period if they do not apply for asylum or get rejected (Kalpouzos and Mann 2015: 6). Also Frontex violated human rights law in transporting asylum seekers from the Greek borders to the detention centres in acknowledgment of the inhumane conditions (Kalpouzos and Mann 2015: 9). Due to that, many people arriving in Greece do not apply for asylum but try to leave the country heading towards other countries in Europe irregularly (Mogiani 2016: 51).

Due to the crisis, many nationalist and racist ideologies emerged especially in Athens, strongly affecting the social living, the political climate and the 
asylum process in Greece (Cabot 2014: 18). Mogiani (2016) also puts these overall societal tendencies in relation to the fast-track procedures for Syrians:

"Since December 2014, Syrians have been able to benefit from a fast-track examination procedure that lets them have an answer within the same day. Unsurprisingly, this generates resentment among those seeking asylum" (Mogiani 2016: 51).

Recently, there are different factors influencing the situation in Greece: the rapidly rising number of refugees (UNHCR 2016b: 1), the change of the Greek government in 2015 (Katsiaficas 2015: 1), the closing of borders in Macedonia and the tendencies of EU-countries to close their borders in general as well as the planned contract with Turkey to close the seaway, fight smugglers and deport asylum seekers back to Turkey (UNHCR 2016a: 1).

Apart from recent research about the rapidly changing asylum related situation in Greece, there is also a research gap regarding asylum and refugee related organisations in general. In the MAREM-project, especially the work and cooperations of these organisations have been regarded how they are influencing each other through cooperation, mutual learning, but also in how far a certain reality of the organisational field is constructed through shared discourses or influences from "above", like paradigms of donors or national and supranational law. One explanatory approach of these dynamics will be illustrated further below.

\section{Neoinstitutionalism}

To embed the recent research in an overall theoretical framework, the theoretical tradition of neo-institutionalism is chosen. It refers to the adaptation of the organisations to their organisational field.

Institutions are defined as a collection of rules and traditions, more or less formalised (Schimank 2007: 162). One can define institutions as "central patterns of social handling of interdependencies" (Schimank 2007: 162). Due to institutions, a set of rules are created where actors can anticipate the behavior of other actors to a certain degree. Also, the participant of the institution is able to orientate at the expectations to simplify social interactions (Schimank 2007: 164). Regarding to that, certain myths of rationality and strategies of problem solution evolve in institutions, which are predominant in each framework and seem useful for the actors. This process mostly leads to alignments of actions and shows the normative influence of institutional practice (Schimank 2007: 165). Therefore, the norms and rationalities of action does not follow objective process of decision, but rather the social constructions influencing the networks and cooperations of actors in a field of action. Sandhu (2012) describes the structures of organisations strikingly as "the mandatory consequence and the result of their societal setting" (Sandhu 2012: 75). 
Different research shows, that often just the formal structure of an organisation is influenced by cooperation and pressure of legitimisation in a strong way, but the informal and actual strategies of action differ from this institutional paradigms. Thus, a so called talk- and action-gap emerges in institutional everyday structures, where actors formally follow the institutional paradigms but rely on the former structures of their own organisations (Sandhu 2012: 74). Organisations often rely on these institutions to survive, hence for receiving the maximum of support it is necessary to legitimate oneself. Because of that, they have to follow certain discourses of institutions in a formal way, nonetheless this reveals little about their informal organisational structure (Sandhu 2012: 76).

Three ways of institutions influencing organisations are central to the theoretical field of neoinstitutionalism: regulative requirements and compulsion, normative exceptions and cultural-cognitive structures of meaning which are not questioned within the societal system (Sandhu 2012: 76).

The prior mentioned processes lead to a process of alignment at the end, which is, regarding to neoinstitutionalism, called isomorphism. The procedure of isomorphism tied to organisations in an institutional field knowing each other and, which is quite more important, observing each other. This observing leads to mutual learning as well as to an institutional alignment because of the already mentioned pressure of legitimisation (Sandhu 2012: 77).

In general, three kinds of isomorphisms are differentiable:

1. Coercive isomorphism: influence of political institutional frameworks and the problem of legitimisation;

2. Mimetic isomorphism: standard responses to uncertainties;

3. Normative isomorphism: fulfilling of normative expectations due to professionalisation.

These three types of isomorphism display an ideal-typical distinction. Because of general social and organisational complexity, these characteristics influence each other and can often not be distinguished (DiMaggio and Powell 1983: 150). These processes of isomorphism and the identification of network dynamics and gaps of talk and action stand in the focus of the recent research of the MAREM-project.

\section{Data and Methods}

To gain a better insight into the dynamics and networks of refugees related organisations in Athens, expert interviews were conducted. Due to that, the interview has a structure which is fitted to the thematic focus of the research, but keeps the structure open to let the interviewees choose their own focus (Pfaffenbach 2007: 159, Mayer 2013: 43). Linked to the network- and neoinstitutionalism focused research of the project, the changes of cooperational networks as well as the isomorphisms were examined. To reach this goal of determining a development of the overall asylum seekers situation 
in Greece and the networks related to that issue, some organisations are interviewed two or three times during the project (2013 till 2016).

In general, the questionnaire which the research relies on, does not only focus on the dynamics of organisational networks. It also is about the refugees situation in Greece and its interdependencies to different social and political factors and dynamics. To get a direct insight into the dynamics of organisations cooperation, questions were posed mainly at the beginning in a formal block, asking directly about their financial resources ("How do you finance your work?"), but also about their cooperation with other organisations ("How important is the cooperation with other organisations for your organisation, on the local, national and international level?") as well as these organisations influences on their work in sense of neoinstitutionalism.

In Athens, 9 expert interviews were conducted in 2014. The interview partners were: NGOs such as Aitima, Hellenic Migration Policy Institute (IMEPO), Amnesty International, Ecumenical refugee program (ERP) and Social Center; governmental organisatons such as police, university and civil society representatives like Afghan Community. In 2015, Aitima, Social Center and Amnesty International gave an additional interview in the project. Besides, interviews with Doctors without Borders, International Organisation for Migration and Antigone could be conducted.

\section{Results}

In 2014, the bad financing situation of all interviewed organisations was striking. Especially NGOs relying on private, but also governmental support reported challenges in getting financial support. Regarding to the theory of neoinstitutionalism, the difficult monetary situation could lead to certain dynamics of isomorphism to acquire new sources to continue their work. Even to get new resources from other organisations or private donors seemed not easy. For example AITIMA, an Athens based organisation providing legal aid, refers about their financing through an EU fond, which is mostly delaying up to 7 month in Greece. Trying to improve their situation, the organisation applied for funding at other organisations and donors but was not able to open up new sources at the time of the interview:

"But this is a really very very difficult and that's why we try to find other sources of funding, which has been proofed as very very difficult, because we apply to foundation to many other organisation but we not easily get funding. We hope that in the future the situation will be improved" (AITIMA 2014).

On the other hand, some organisations try to remain independent especially from the government. For example, the Social Centre Athens keeps independent through selling food and drinks as well as from members, 
especially because they see the government as part of the problem, so one could speak of conscious rejection of isomorphism.

Another factor that can be linked to the organisations network and their work and influence on each other is the high number of networks, mostly including NGOs. Some interviewees talked about networks to help each other and especially exchange knowledge and experience on local, national and international level as well. Amnesty International Greece even told about the sharing of resources, especially in research. These high numbers of networks and NGOs involving in it in Greece could probably lead especially to mimetic isomorphisms, resulting from mutual learning, sharing of resources and even adaption of certain discourses just because of closely working together. There were also attempts to build networks in a broader framework, for example AITIMA:

"During last year we became member of three European networks: one is ECRE and the other is PICUM and third is ENA - European Network Against Racism. So this is good for our organisation because it means that our work is recognised and on the other hand this enables us to advocate at the European level" (AITIMA 2014).

This attempts to get higher recognition especially on European level could lead to the takeover of certain paradigms which are predominant, and therefore to coercive isomorphism. Also IMEPO, a former governmental and recent nongovernmental organisation, mainly cooperates on international and EU-level and gets funding from EU as well, so this strong connection could lead to coercive as well as mimetic isomorphism. In case of international cooperation, the interviewee even explicitly refered to mimetic isomorphism:

"We give some information to them because we try to learn from the other countries with similar problems like Greece. Of course the situation here is very different from every other country in the EU" (IMEPO 2014).

Many refugee related organisations, especially NGOs, try to fill the gap between talk and action of the Greek government emerging from the process of discoursive Europeanisation. Some of the organisations interviewed in 2015 especially criticised the lacking capacities for registration and supply of asylum seekers in Greece. That results in missing support for asylum seekers in almost every sphere of live.

Because of the governments missing ability or will to ensure an appropriate supply of asylum seekers mostly reaching Greece from the Aegean, many NGOs settled down in Greece to provide basic service, e.g. the first medical screening of asylum seekers by Medicins sans frontiers (MSF) in their mobile hospitals mainly located at the Agean islands and to improve partly the living condition in Greek detention centres - one representative states in this context: "Detention is torture" (MSF 2015) - or helping them with finding an 
accommodation or to get a working permission by the International Organisation for Migration (IOM).

Mainly, in 2015 there was nearly no support of NGOs by the Greek government and little cooperation networks between governmental and non governmental organisations, so they had to draw their financial resources from private sources. MSF even emphasised their independence from government support to work autonomous to be able to criticise the inhumane living conditions of many asylum seekers in Greece:

"All the projects related to migrants, asylum seekers and refugees in an European context (...) are $100 \%$ finance by private MSF funds, we don't take a single Euro by the Greek State or European Union, because we believe they are responsible for that, to take money from them it is difficult to criticise them" (MSF 2015).

This quotation even shows the deliberate rejection of legitimisation in sense of isomorphism to work in compliance with the NGOs perception of the dynamics of migration in the EU.

On the other hand, AITIMA explicitely refered to the funding of the Greek government to other organisations and an important part of producing isomorphism by funding:

"The authorities are more or less responsible for the fund and implementing projects, so it is more important what the state wants to do" (AITIMA 2015).

To work in an appropriate way, representatives of NGOs call cooperation networks between different refugee related organisations essential. As well as in 2014, Amnesty International Greece mentioned networks for doing their research in a proper way:

"It's a key element. We cannot do what we do without the other organisations (...) even in research field we work close within a platform, national and international, we exchange information regularly" (Amnesty International 2015).

Also MSF referred to cooperation networks in a positive way. They mainly use these networks to provide a better service for asylum seekers and refugees and coordinate their "missions".

Even if the goals of the diverse NGOs are differing, they try to build new networks and formulate common goals in helping asylum seekers in Greece. Especially because of the limited ressources due to little support of governmental authorities, NGOs representatives see close cooperations and good working networks as an indispensable part of their work. Due to that, organisations are able to support each other, share knowledge and forward 
asylum seekers to other NGOs in case of shortages in working or financial capacities.

Regarding CEAS and EASO, many organisations criticised the ignorance of pecularities of Mediterranean countries. There is little help with registration, accomodation or the redistribution of refugess within the EU.

In general, the hopes of the refugee and asylum related organisations in Greece rely on the new government of SYRIZA. In March 2015, the new governmental party already started to release asylum seekers from detention centres and shorten the maximum length of stay to six month, but the interviewed organisations remain sceptical at the beginning of the legislative period, partly because of experiences of gaps between talk and action of SYRIZA, as AITIMA stated:

"The new government said that they will fulfill international regulations, that means that people will be able to apply for asylum and have a fair examination of their asylum applications because now we have the New Asylum Service but we don't have branches all over the country, this means that access to the asylum procedure is not granted" (AITIMA 2015).

The interviewee of AITIMA also gave a hint about possible isomorphisms due to the governments change because of new paradigms in the sense of talk is entering the governmental level:

"And now we think we will have better cooperation with the government, because the people who work now in the government are from the civil society (...)" (AITIMA 2015).

Further developments due to the governments change are examined by the MAREMs round of 2016. Due to that far reaching changes in Greece, the empirical work seems promising in 2016. Looking at these political and social developments, the following assumptions are stated: Due to the political changes and discoursive processes, the isomorphisms as well as networks could change in the future, even in cooperations funded by the former government to legitimise their work. Also, the precarious situation for refugees due to persisting and new difficulties induces the proliferation of organisations and their perceived mission to fill the governments gap of talk and action.

\section{Conclusion}

Regarding the asylum system and the asylum related situation in Greece, several developments took place formally. During the crisis, a new migration law was implemented which later got annulled. This could be seen as a result of the financial crisis and the rising number of asylum seekers trying to get access to the EU through the Aegaes. Also the asylum procedure underlied 
different changes, which should improve the process and make it more transparent, partly resulting from EU guidelines. One could speak of isomorphism in the case of some refugee related organisations in Greece. Nevertheless the formal changes in Greece did not bring large scale improvement to the social reality of asylum seekers. Especially the situation in detention centres are alarming, worth mentioning in particular overcrowded arrest cells with poor hygienic conditions. This definitely shows a gap between talk and action in Greek politics, that refugee related organisations try to fill while trying to improve the overall living conditions for refugees in Greece. Especially the governments change raised hope for most of the organisations representatives in the last year, when the results of the changing politics could not be analysed properly.

From the years of 2014 and 2015, some assumptions about isomorphism can be stated:

Because of the lacking financial and cooperational support of the Greek government, there is little probability that NGOs feel to legitimise themselves. Some of them even emphasise their independency from the government. Because many organisations rely on private ressources, normative isomorphism could have taken place. Due to the close cooperation networks in Greece, there could also have been some mimetic isomorphisms. Often, cooperation networks are limited to the national level, but some organisations try to extend their sphere of influence to the national and European level. This could lead to new dynamics regarding representing Greece in the EU and isomorphisms possibly having effects on the local level again.

Refering to statements of the interviewees, gaps in talk and action are especially getting visible on national and European level and their interdependencies. On the one hand, Greece tries to fulfill EU guidelines and "imitates" their discourses, on the other hand, the EU and EASO is propagating a common Europe where the burden is shared, but is providing little help to Greece.

Regarding to recent developments, further research and observation seem appropriate. Some aspects can be covered by the last round of MAREM-project 2016.

\section{References}

Cabot H (2014) On the Doorstep of Europe. Asylum and Citizenship in Greece. Pennsylvania: Penn Press.

DiMaggio PJ, Powell WW (1983) The iron cage revisited: Institutional isomorphism and collective rationality in organizational fields. American Sociology Review 48(2): 147-160.

Gansbergen A, Pries L (2016): Zwischen ,Festung Europa“ und ,Raum der Freiheit, der Sicherheit und des Rechts': NGO-Netzwerke in der Institutionalisierung eines europäischen Flüchtlingsregimes [Between "Fortress Europe" and "Space of Freedom, Safety and Rights": NGO-Networks in the Institutionalisation of the European Refugee Regime]. In S Lessenich (Ed): Routinen der Krise - Krise der 
Routinen. Verhandlungen des 37. Kongresses der Deutschen Gesellschaft für Soziologie in Trier 2014, 1-15.

Georgiadou V, Rori L (2013) Economic crisis, social and political impact. The new right-wing extremism in Greece. Anuari del Conflicte Social, 322-339.

Kalpouzos I, Mann I (2015) Banal Crimes against Humanity: The Case of Asylum Seekers in Greece. Melbourne Journal of International Law 16(1).

Katsiaficas C (2015) A New Day for Greek Migration Policy? The New Government and Prospects for Reform. BRIEF Commentary 33(1): 1-5.

Mayer HO (2013) Interview und schriftliche Befragung. Grundlagen und Methoden empirischer Sozialforschung: Interview und schriftliche Befragung [Interview and written survey. Basics and Methods of Empirical Social Research]. München: Oldenbourg Verlag.

Meyer JW, Rowan B (1977) Institutionalized organizations: Formal structure as myth and ceremony. Amercian Journal of Sociology 83(2): 340-363.

Mogiani M (2016) Passing through Greece. Forced Migration 51(1): 51.

Oliver C (1991) Strategic Responses to Institutional Processes. Academy of Management Review 16(1): 145-179.

Pfaffenbach C (2007) Methoden qualitativer Feldforschung in der Geographie [Methods of Qualitative Field Studies in Geography]. In H Gebhardt, R Glaser, U Radtke, P Reuber (Eds), Geographie, 157-164. München: Physische Geographie und Humangeographie.

Pries L, Gansbergen A (2016) The Mediterranean Refugee and Asylum Regime "Ugly Side of the European Space of Justice, Freedom and Security" or "Humanitarian European Asylum System in the Making"? [in Peer-Review].

Sandhu S (2012) Public Relations und Legitimität [Public Relations and Legitimacy]. Wiesbaden: VS Verlag für Sozialwissenschaften.

Schimank U (2007) Neoinstitutionalismus. [Neoinstitutionalism]. In A Benz, S Lütz, U Schimank, G Simonis (Eds), Handbuch Governance. Theoretische Grundlagen und empirische Anwendungsfelder, 161-175. Wiesbaden: VS Verlag für Sozialwissenschaften.

Tirandafyllidou A (2014) Greek migration policy in the 2010s: Europeanization tensions at a time of crisis. Journal of European Integration 36(4): 409-425.

UNHCR (2015) Over one million sea arrivals reach Europe in 2015.

UNHCR (2016a) Winter Operations Cell, 25 Feb 2016.

UNHCR (2016b) Greece data snapshot, 25 Feb 2016. 